\title{
Many Unanswered Questions
}

\author{
BY \\ ALIAKSIEJ LASTOǓSKI
}

\begin{abstract}
Piotr Rudkoŭski
Białoruskie pytania w kontekście europejskich odpowiedzi, Kolegium Europy Wschodniej: Wojnowice, 2017. 311 pages.
\end{abstract}

ISBN: 978-83-7893-111-9

Piotr Rudkoŭski's latest book is published by the Wroclaw College of Eastern Europe publishing house under the title 'Belarusian Issues in the Context of European Responses'. The book consists of three sections under the headings 'Associations,' 'Challenges' and 'Proposals.'

Whereas Belarus is usually identified with Lukashenka, the Soviet legacy and national nihilism, Europe is identified with humanitarianism, secularism, the community of nations and critical discussion. However, the author considers these usual associations from a critical perspective. The Europeanisation of Belarus is considered in 'Challenges,' but the bulk of the book's content appears in the third part, 'Proposals,' which addresses the main problems of Belarusian humanitarian thought and applies the rules of critical discussion to a range of issues including Belarusian philosophy, various paradigms of the national idea, and discussions about religiosity and secularism, gender studies and abortion.

The title of the book sounds very ambitious, no less ambitious is its content: the author criticises not only the Belarusian reality, and especially humanitarian practices in the domestic context, but also trends in development of the European thought. In addition to the two components mentioned in the title - Europe and Belarus - one could add a third, Poland, since the author's strong engagement with the Polish context is clearly felt. This is not accidental bearing in mind that Rudkoŭski wrote the book during his residence in Poland on the Lew Sapieha scholarship. In any case, knowledge of Polish public discourse furnishes the author with critical insights into the trends and intellectual pitfalls of our time.

I published my first public review in the journal ARCHE in 2008. By coincidence, it was a review of Rudkoŭski's book on the Belarusian national idea. ${ }^{1}$ That review

\footnotetext{
1 Lastoŭski, Aliaksiej, 2008. Budaŭnictva bielaruskaj nacyi praz intelektuaĺnaje vyniščennie apanientaŭ, $A R C H E, 11$.
} 
was highly critical, which could easily be attributed to youthful fervor. Age teaches restraint in one's expressions and due credit should be given to Rudkoǔski: in the years since he has strengthened and even enhanced the intellectual landscape of Belarus, which could never be described as diverse and blossoming. Rudkoŭski has become a unique figure for Belarus, and we must appreciate him for this.

He is noteworthy for his commitment to the school of analytical philosophy, which remains unpopular in Belarus. Strangely, at the time of post-Soviet transformations, when a multitude of doctrines and intellectual traditions seeped into the Belarusian philosophical space, analytic philosophy made no mark despite its prominence in the Anglo-Saxon world. With his love of analytical philosophy and the absence of any like-minded people, Rudkoǔski appeared something of a black sheep. At the same time, this gives him the necessary distance to effectively dissect the Belarusian intellectual scene.

We cannot but mention yet another peculiarity of Rudkoŭski's thinking the strong influence of Christian conservatism; another rarity in the Belarusian intellectual realm. Yet this is not the mossy conservatism of religious fanatics, as some like to represent it. Instead Rudkoŭski is thoughtful and socially committed, so that his conservatism through the love of God stimulates him to take an active position in the world and improve it.

From this position, Rudkoŭski criticises the reality of modern Europe. For him the discourse of humanitarism and the priority it affords human rights leads to a revision of sexual roles, where Europeanness is identified with secularism. This creates a struggle with religious symbols, where atheism is propagated and Satanism spreads openly, and where European integration calls into question national sovereignty, and where, importantly, the principles of critical debate are eroding. Rudkoŭski's position is in tune with the criticism of the European project common among the Polish intelligentsia, especially among Catholic conservatives. On the other hand, Rudkoŭski provides this criticism succinctly, which clearly requires a detailed description, and therefore I will not elaborate on it here.

Rudkoŭski's analysis of the Belarusian situation offers much more interesting material. The author first analyses the representation and prevalence of pro-European views in Belarusian society, which will interest Polish readers, and proceeds to criticise the Belarusian intellectual discourse. The author endows this discourse with the following unsightly traits: the ignoring of facts in favor of ideals and thinking in terms of mission, holism, and the domination of unverifiable assertions. It is clear that such accusations require that the author maintains exceptional intellectual purity and rigor, but this is not always the case with Rudkoŭski. 
The first target Rudkoŭski takes aim at is Belarusian philosophy. He places his main focus not on the official and institutionalised philosophy, which is in such a terrible state in Belarus that censure is futile, but on the independent philosophy outside state intitutions. The thinkers belonging to this group produce worthy texts and present more food for discussion. The main reproach that Rudkoŭski directs at this sphere is its methodological anarchism; a complete disconnection from the Western European scientific method. One case he specifically discusses is a methodological society that exists around Uladzimir Mackievič. It surprises Rudkoŭski that this society does not lend itself to the standards of analytical philosophy.

Most importantly, Belarusian thinking actually exists either on the border of philosophy and literature (under the hefty influence of Valiancin Akudovič and Ihar Babkoŭ), or on the border of philosophy and political practice (as in the case of Mackievič's circle). Indeed, it remains diffuse, borderline and bombastic. It differs from the transparency and logic of Karl Popper's students or representatives of analytical philosophy.

We can criticise and unpick the ideas created in the Belarusian intellectual space from different perspectives - analytical philosophy, existentialism, postmodernism, and such forth. But does not such a rigid position lead to schematism and sifting everything alive and new that has grown on the Belarusian soil? In my view, some of the objects of Rudkoŭski's criticisms represent the stronger aspects of Belarusian thinking, which give it authenticity, originality, and style, rather than its weaknesses. The more important task is not transferring our philosophy to the framework of analytical standards, but rather to create centres that will develop these approaches locally, which the author recognises himself. But who will do it and who will be responsible? It is very easy to criticise from outside, but very difficult to create something new, strong, and alive.

For me, as someone outside of philosophical discourse, the next section of the book, which is devoted to the analysis of the Belarusian national idea, presents greater interest. Earlier, in his book 'Białoruska idea narodowa w XXI wieku' (The Belarusian National Idea in the 21st Century, 2008), Rudkoŭski proposed dividing national discourse into left, right and centrist. In the review mentioned earlier in this text, I questioned the value of this classification, and the author (regardless of my criticism, which he did not accept) now offers another approach for determining the three competitive paradigms of the national idea, created through an analysis of Belarusian historiography: revivalist (Belarusian national historiography), WestRussian (Zapadnorusizm) and constructivist.

Here one must pay attention to the peculiarity of Rudkoŭski's methodology, namely, the problematic representativeness of his source texts. I could tolerate the 
mix of quotes from Valiancin Akudovič and Česlaŭ Kirviel, a professor at Hrodna University, in the preceding section, although I do not understand how these two authors can be placed in a single category.

In order to criticise Belarusian national historiography, the author uses the works of Zianon Pazniak and the multi-page opus of Anatol Astapienka 'Igde zarodilisia i uskormleny sut' po Boze' (2009), which Rudkoŭski for some reason considers important. This move surprises: why were the ideological treatises (which in the case of Astapienka have raff intellectual values) chosen for an analysis of historiography? What about the adherence to the principles of methodology on which Rudkoŭski firmly insists? The author singles out 'a reference to authority whose views are irrelevant' (p. 209) as a typical flaw of the Belarusian intellectual space, but in this case he demonstrates his belonging to the same space and commits the same flaw he so passionately criticises. Hence, it is pointless trying to understand why the author engages Astapienka's work, since the latter has nothing in common with the development of Belarusian historiography.

Of the three paradigms listed above, Rudkoŭski focuses most of his criticism on the constructivist approach. He gives particular attention to Valier Bulhakaŭ's work 'Istoria belorusskogo natsionalizma' (The History of Belarusian Nationalism, 2006), which sparked heated debates and has been harshly criticised in the past. Rudkoŭski also notes certain positive features of the constructivist approach, in particular its problematisation of the correlation between the name of the country, the nation and the language. But the main point of criticism from the perspective of analytical philosophy is the vagueness of basic categories of the constructivist approach, including its imagined community concept. The author strongly urges us 'not to be afraid of abandoning constructivist jargon and returning to normal language' (p. 201).

After the defeat of the constructivist approach, he turns to the concepts of the nation put forward by Andrej Kazakievič. According to Rudkoǔski, this approach definitely has its strengths, including its emphasis on wide-ranging empirical materials, but at the same time uses inaccurate categories and lacks coherence.

The most important objects of the author's criticism are feminist theory and gender studies, which appear in the last part of the book. Quite predictably, his criticism unfolds along three main lines: methodological weakness, the manipulation of concepts, and the tendency to ignore scientific principles, which generally poses a question whether we are dealing with scholarship at all, and not with strategies for indoctrination (p. 277). Another line of criticism is related to Christian humanism and primarily concerns the problem of abortion. Here Rudkoŭski builds a very strong line of argument against abortion, drawing on the latest biological research. 
To sum up, we have received a 300-page book full of criticism, debate and heated discussions. The main problem of the book is perhaps that it attempts to discuss too many topics. Like Don Quixote, the author tilts at every possible windmill on the horizon, not knowing his own strength. The book contains a lot of superficial criticism, worthy of further consideration, reflection and elaboration. The criticism of constructivism and gender studies appear the most powerful and interesting, and this debate really can enrich the Belarusian intellectual space. However, if the author concentrated solely on this and discarded everything superfluous, it would be much easier to perceive his ideas. 